\title{
Tugwaardige sondes in drie gereformeerde kerkordes
}

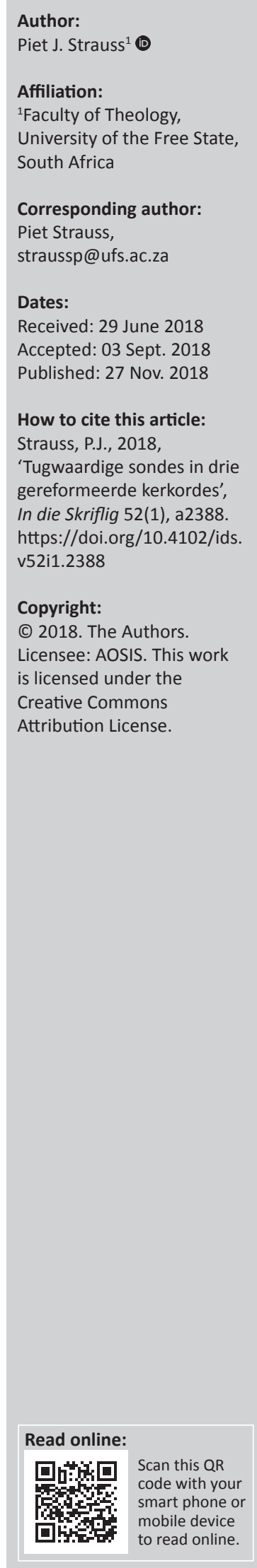

Sin which should be disciplined according to three church orders. The orders of three reformed churches, namely those of the Dutch Reformed Church, the Christian Reformed Church in North America and the Reformed Churches in South Africa have consensus about the need for an officially punishable sin to be of a public and offensive nature. The reason is that a sin must be openly against the Word of God and the confessions of the church. The approach of the church as an institution of faith carrying the love and righteousness of God, should be to maintain the spiritual nature of church discipline and to aim for the spiritual purpose of its discipline. Church discipline should be aimed at convincing the sinner and assuring church members of its desire to keep the demands of the Word and justice in tact.

\section{Inleiding}

Die Dordtse Kerkorde van 1619 (DKO 1619) artikel 71 bepaal dat die 'Christelijke straf' of kerklike tug $^{1}$ geestelik is en niemand - geen lidmaat ${ }^{2}$ - van die burgerlike straf of 'gericht ... bevrijdt' nie (Pont 1981:184). In sy kommentaar hierop bevestig Jansen dat die kerklike tug, getrou aan die aard van die kerk, geestelik is en die oortreder nie van die publiekregtelike strafproses van die staat vrystel nie (Jansen 1952:303; vgl. Van der Vyver 1972:84).

Voorts wys Jansen (1952) daarop dat die gereformeerde kerkvaders van die sewentiende-eeuse Nederland die 'approbatie' of goedkeuring van die staatsowerheid vir hulle kerkorde wou kry omdat dit daardeur die status van 'n landswet met meer gesag as 'n kerkorde sou besit. Die owerheid het egter gevrees dat die Gereformeerde Kerk sy mag kan oorskry deur homself 'burgerlijke macht' aan te matig en regspraak uit te oefen oor hulle wat nie aan hierdie kerk behoort nie. ${ }^{3}$ Daarom het die Nasionale Sinode van Dordrecht in 1619 verklaar dat die kerklike tug lidmate nie van die burgerlike straf onthef nie. Om sy kerkorde deur die landsowerheid aanvaar te kry, moes laasgenoemde daarvan verseker word dat die kerk nie met hom sou meeding om die monopolie van sy swaardmag oor ' $n$ bepaalde gebied of staatsterratorium nie (Jansen 1952:303; vgl. Van der Vyver 1972:84).

Waarvan DKO artikel 71 ook gewag maak, is die prinsipiële onderskeid tussen die aard van die kerklike tug en die burgerlike straf. Agter hierdie bepaling van DKO 1619 staan die gereformeerdprinsipiële of Calvinistiese onderskeid tussen kerk en staat - 'n onderskeid wat in embrio na Calvyn teruggevoer kan word (Sizoo III s.a.:555-559). Die uitvloeisel hiervan is wat van der Vyver in staatsfilosofiese taal omskryf as die 'kompetensie' van die kerk om sy eie 'reg' te vorm en toe te pas - 'n reg op sy eie prosedure en optrede wat uit die unieke aard van sy struktuur 'as samelewingsverband' of 'n instelling of kring van die Christelike geloof spruit (Van der Vyver 1972:189) - bepalings wat uit sy 'geestelike bestuurswyse' voortvloei soos in artikel 30 van die Nederlandse Geloofsbelydenis (NGB) aangetoon. Dieselfde artikel 30 beskou kerklike ampswerk as geestelike werk wat inhou dat die ware leer en godsdiens (leer en lewe) onderhou en oortreders op 'n 'geestelike wyse' vermaan en in toom gehou word (NG Kerk-Uitgewers 1982:30).

In sy bepalings oor die kerklike tug verwoord die kerkorde van die Nederduitse Gereformeerde Kerk van 2017 (NGKO 2017) hierdie uitgangspunt so:

Die kerklike opsig en tug dra'n geestelike karakter en pas by die kerk as'n geloofs-en'n liefdesgemeenskap. Opsig en tug word dus op 'n kerklike wyse en met geestelike middele uitgeoefen. (bl. 16)

1.Die saak waarom dit hier gaan, is die oorredende karakter van kerklike geloofstug in onderskeiding van die dwingende strafreg van die staat deur sy swaardmag, die ouerlike tug as ' $n$ liefdestug of die vereniging se skorsingsreg in terme van sy doelstellings. Soos die kerklike tug kan hierdie ander soorte tug egter ook Christelik wees. Deur die Christelike tug vir die kerk te reserveer, word hierdie bybelsverantwoorde moontlikheid ontken. Daarom moet die DKO se 'Christelike tug' met 'kerklike tug' vervang word. Vergelyk in hierdie verband ' $n$ moderne moontlikheid ontken. Daarom moet die DKO se 'Christelike tug' met 'kerklike tug' vervang word. Vergelyk in hierdie verband ' $n$ moderne
weergawe van die Nederlandse Geloofsbelydenis artikel 29 wat ook by die Dordtse Sinode in Mei 1619 aanvaar is met sy 'kerklike tug' as een van die merktekens van die ware kerk (Donner \& Van den Hoorn s.a.:325; NG Kerk-Uitgewers 1982:29; Polman III s.a.:309).

2.Die kerklike tug strek hom uit oor die doop- en belydende lidmate wat hulle onder die opsig en tug van die kerkraad van ' $n$ bepaalde gemeente bevind. So 'n kerkraad kan nie-lidmate vermaan, maar nie die volle pad van die tug met hulle loop nie omdat lidmate hulle 'vrywillig', maar gebind deur hulle geloofsoortuigings, aan die opsig van 'n kerkraad onderwerp (Nauta 1971:355).

3. Kyk voetnoot 2 . 
Dat die kerklike tug geestelik van aard is, vorm 'n kerkordelike konsensus in die drie kerke wie se kerkordes hier ter sprake kom: die Christian Reformed Church in North America (CRC-NA), die Nederduitse Gereformeerde Kerk (NGK) en die Gereformeerde Kerke in Suid-Afrika (GKSA) (Strauss 2017) - drie kerke wat 'n kerkhistoriese 'konneksie' of band met die Gereformeerde Kerk in Nederland van die sestiende en sewentiende eeu het. Die drie kerke vertoon ooreenkomste met hierdie kerk in hulle kerkordes waar dit tugwaardige sondes behandel - sondes wat amptelik deur kerkvergaderings soos kerkrade, ringe of klasses en sinodes as die bevoegde tugliggame van die kerke hanteer word (NGKO 2017:16-19; Visser 1999:264-304). Die DKO praat van tugwaardige sondes as openbare, ergerlike sondes; die kerkorde van die GKSA of die GKSA-KO van openbare, growwe sondes; die kerkorde van die CRC-NA (CRC-KO) van 'sins with a public nature'; en die NGKO 2017 van sondes wat openbare aanstoot gee (DKO 1619 artikel 71-76 in Engelhard \& Hofman 2001:442; NGKO 2017:17; Pont 1981:184-185; Visser 1999:264-265, 283). Hoewel hulle terme verskil, gaan dit by al drie om sondes van 'n openbare en ergerlike of aanstootlike aard.

Die probleem wat hierdie artikel ondersoek, is hoe hierdie tugwaardige sondes deur kerkvergaderings van genoemde drie kerke van ander sondes onderskei word. Wat maak 'n sonde vir hulle tugwaardig? Is daar gelysde tugwaardige sondes wat as sodanig kwalifiseer vir 'n tughandeling of word ' $n$ saak in sy omstandighede met alles wat daarmee verband hou, ondersoek? Is dieselfde maatreëls van die kerkorde van toepassing op tugsake in leer en lewe? Indien alle lidmate getug kan word, sluit dit dooplidmate in?

\section{Tug in gereformeerde kerke?}

Teenoor die Nederlandse Geloofsbelydenis artikel 29 wat die ware kerk onder meer daaraan uitken dat dit die 'kerklike tug gebruik om die sondes te straf' (NG KerkUitgewers 1982:29), stel Koffeman (2009:282) dat die kerklike tug vir baie gereformeerdes in 'n kerklik-plurale Nederland verword het tot 'n 'inhoudloze kerkordelijke aangeleentheid'. Vir hulle is die tug nie meer 'n hulpmiddel vir die kerk om sy roeping te vervul nie. Hulle bevind hulle in 'n situasie waarin etiese beslissings oor reg en verkeerd soos in die gay-kwessie - aan die heersende kultuursituasie toegeskryf word. Hulle maatstaf is die opvattings vir menslike gedrag in 'n sogenaamde moderne Christelike samelewing en nie eksplisiete, verantwoorde bybelse vertrekpunte of konstantes nie. Daarom negeer hulle die moontlikheid van Woordgebonde tug. Vir hulle is die Christusregering in die kerk as 'n regering deur sy Woord en Gees en daarmee die kerklike tug net nie meer 'n realistiese moontlikheid nie (Koffeman 2009:282).

Hierteenoor beskou kerke wat konsekwente Christusregering in die kerk as regering deur die Woord en Gees van God beskou, in die woorde van Bouwman, die kerklike tug 'als de handhaving van de heerschappij van Gods Woord in de kerk'. Vir hulle impliseer die suiwere bediening van die Woord en die sakramente as Woordbepaalde genademiddele, kerklike tug (Bouwman 1985:601). In aansluiting hierby oordeel Keet (1963:89) dat 'weinig sake ... van meer belang is vir die gesonde lewe van die kerk en wat ... meer misverstand ondervind ... as die kerklike tug'. In kommentaar op die CRC-CO, werk Engelhard en Hofman (2001:441) met die uitgangspunt dat die kerklike tug in die liefde van God gegrond is en in die hart van die kerklike bediening lê en voeg daaraan toe: 'Discipline is at heart discipling ...'.

Die opmerkings van Smit (2009) in 'n ander verband versterk hierdie standpunt. Volgens Smit skenk die Here aan sondaars wat dit nie verdien nie, 'n verlossende, toegekende geregtigheid of 'compassionate justice' om Christus ontwil. God is in sy geregtigheid bekommerd oor die verlossing, genesing, herstel en redding van die slagoffers van die gebrokenheid en diegene wat vergifnis, nuwe geleenthede en 'n tweede kans of herstelde lewe nodig het. God se geregtigheid is 'n omgee- of verlossende geregtigheid en 'n bewys van sy verbondstrou (Smit 2009:377). 'n Mens sou daarby kon voeg, 'n omgee of verlossing wat ook gestalte in die tug van kerklik-tugwaardige sondes kry - kerklike tug of herstelwerk waardeur die sondaar Christelike liefde ontvang: '... die Here straf die mens wat Hy liefhet net soos 'n vader doen met sy seun'. ${ }^{4}$

NGKO 2017 omskryf sondes wat tot kerklike tug lei as sondes wat teen die Woord van God en die belydenis van die kerk 'indruis' (NGKO 2017:17). ${ }^{5}$ Ten diepste druis sondes wat deur kerkvergaderings hanteer moet word in teen die Bybel en die belydenisskrifte van gereformeerde kerke wat die kernwaarhede van die Skrif oor die drieënige God en ons redding wil sistematiseer (Jonker 1994:6). Die kerklike tug moet in liefde die harte van sondaars wen sowel as lidmate bewaar van 'dwalinge', weg van die Godgehoorsame leer en lewe af. Juis daarom waarsku Engelhard en Hofman (2001) teen selfregverdiging, wraakgierigheid en liefdeloosheid by tugvergaderings. Hulle (Engelhard \& Hofman 2001:441) voeg hieraan toe: die ouderlinge (lede van tugvergaderings) moet groot geduld in die tughandeling (deur ondersoek en optrede) aan die dag lê - geduld wat daarop ingestel is om die begrip en gesindheid van die werklike oortreder deur innerlike oortuiging te wen en so iemand tot berou en inkeer te bring. Om die argument van Smit ook vir tugwaardige sondes te gebruik: dit gaan hier om die kerk as die instrument van God se toegekende, verlossende geregtigheid wat die sondaar in hart en lewe vir God se saak wen.

Ander gereformeerde kerke verwoord die Woord as die norm van die norme (norma normans) meer implisiet vir tugwaardige

4.Vergelyk hiervoor Spreuke 3:11-12 as locus classicus -'n vers en'n tema wat later in Hebreërs 12:6 opgeneem word.

5.In 1978 word die NGKO (1978:15) op hierdie punt verander met die byvoeging dat tugwaardige sondes teen die Woord die belydenis van die kerk sowel as die Kerkorde indruis. Hierdien dis Kerkorde indruis. Hierdie by die NGK plaas - $n$ era waarin daar aan die Kerkorde meer gesag toegeken is as blote ordereëls of ordelike kanale vir die kerklike lewe. In hierdie klimaat belas die Algemene Sinode van 1974 kerkvergaderings in die NGK boonop met ' $\mathrm{n}$ niegereformeerde tugreglement van 'n omvangryke 22 bladsye (Sadler 1979:33-34). NGKO (1998) skrap egter 'die Kerkorde' as 'n bykomende begrip op hierdie punt en raak van die tugreglement ontslae (NGKO 1998:21). 
sondes, maar handhaaf die beginsel. Hoewel hulle dit nie in kerkorde-artikels opneem nie, doen hulle dit as verklaarde Woordgebonde gereformeerde kerke.

\section{Tugwaardige sondes is openbare sondes}

In hierdie konteks maak die CRC-CO gewag van oortredings 'that give public offense' en wat daardeur onder die aandag van die kerk kom. Dit kan ook oortredings wees wat via die stappe van Christus in Matteus 18:15-17 eventueel op die agenda van 'n kerkvergadering beland (Engelhard \& Hofman 2001:442) - openbare aanstoot en die gebruik van Matteus 18 (op hierdie punt is die Woord van God ook normatief) wat impliseer dat die Woord in leer en lewe in gedrang kom. Die GKSA-KO gebruik ook hierdie bronne vir 'n tugsaak op 'n kerkvergadering. Vir die GKSA-KO gaan dit om tugwaardige sondes in die lig van die 'suiwerheid van die leer of vroomheid van die wandel' - sake wat aan die hand van Matteus 18 of vanweë openbare kennis op die kerklike agenda geplaas word (Spoelstra 1989:391; Visser 1999:264, $266,275,283)$.

In sy verklaring van die GKN-KO van 1959 wat as 'n eietydse weergawe van die DKO beskryf is (Strauss 2010:7-8), begin Nauta sy kommentaar op die kerklike tug by GKN-KO artikel 104 wat Calvyn se drieledige doel vir die kerklike tug in hom opneem: die verheerliking van God, die behoud van die sondaar en die verwydering van 'n ergenis uit die gemeente (Sadler 1979:15; Sizoo III s.a.:5, 10). Vir Nauta (1971) bepaal hierdie doel die geestelike aard en inhoud van die kerklike tug. Tugwaardige sondes kan by alle lidmate voorkom en spruit uit sake van belydenis en lewenswandel sake wat eweneens weens hulle openbare aard of via die stappe van Matteus 18 'amptelik' op die agenda van 'n kerkvergadering beland. Die GKN-KO wys by implikasie op die Woord as norma normans of hoogste norm as hy dit het teen afwykings van die 'gesonde leer' en 'godvrezende wandel' (Nauta 1971:348, 351-352).

Nauta oordeel tereg dat die geestelike bestuurswyse van die kerk en die kerklike tughandeling as 'n geestelike handeling bepaal dat kerklike besluite deur middel van oortuiging werk. Die bevindings van kerkvergaderings in tugsake bind en bekeer gelowiges slegs deur innerlike oortuiging in 'hart en siel'. Ten diepste gaan dit hier om oortuiging deur die Woord en Gees van God. Dit is 'n oortuiging wat spruit uit vertroue by die betrokkenes dat die aangewese tugwaardige sonde deur die Woord blootgelê en hulle deur die betrokke kerkvergadering regverdig behandel is - ' $n$ vertroue wat bou op die stellige sekerheid dat die kerk Woordgetrou in almal se geloofsbelang wil optree (kerklike regsekerheid); dat die kerk almal se reg op regverdigheid in 'n Christelike geloofsgemeenskap erken en nie met 'n heksejag of 'n openbare kragvertoon besig is nie. Coertzen (2003) praat van regsbeskerming in die kerk wat verseker dat lidmate met sekerheid kan aanspraak maak op die handhawing van die amptelike prosedure of orde van die kerk sowel as sekere - in die lig van die Skrif - geregverdigde menseregte. Lidmate kan dus aanspraak maak op 'n kerklike regsproses wat uit die unieke eie aard van die kerk as 'n kerk van die Woord vloei sowel as bou op die reëls vir natuurlike geregtigheid, of anders uitgedruk, 'n bybels-erkende regverdigheid (Coertzen 2003:199-215; Du Plooy 2007:18vv; Sadler 1979:51).

Gemeet aan die drie genoemde kerkordes teen die agtergrond van die gereformeerde kerkreg, is tugwaardige sondes (sondes hanteer deur amptelike kerkvergaderings) in die eerste plek sondes of oortredings in die lig van die Skrif en die kerklike belydenis wat in die openbaar, of ten minste, aan 'n deel van die gemeente bekend is - openbare sondes wat ook bekend of openbaar kan word deur die stappe van Matteus 18:15-17.

Die betrokke kerkvergadering moet oordeel of die beweerde sonde reeds van 'n openbare aard is en daarom ter tafel geneem kan word. Genoemde drie gereformeerde kerkordes laat die bepaling van dit wat openbaar is, in die diskresie van die betrokke kerkvergadering. Nêrens is daar ' $n$ aanduiding van direkte, eksakte maatstawwe vir 'n openbare sonde nie. Dit gaan oor die vraag of die sonde bekend is, afbreuk doen aan die beeld van die kerk as die gemeente, gebou of tempel 'van God' (1 Kor 1:2; 3:9, 16, 17) en negatief op die geloofslewe van gemeentelede inwerk. 'Afbreuk' en 'negatief' word gekoppel aan die uitdrukking 'van God' wat impliseer dat die hele lewe van die gemeente en elke gemeentelid die karakter moet dra dat hierdie lewe van God kom. Hierdie oorwegings is breë aanduidings wat deur ' $n$ kerkvergadering in sy diskresie aangewend word. Sadler voer aan dat die bekendheid van 'n sonde 'n relatiewe maatstaf is wat na die aard en omstandighede van die gemeente aangewend moet word. As ' $n$ sonde in 'n klein gemeente aan vyf persone bekend is, kan dit openbaar wees, terwyl dit in 'n groot gemeente nie die geval is nie. Elke geval moet binne sy konteks beoordeel word (Sadler 1979:60).

Plomp wys daarop dat die eerste Nasionale Sinode van die Gereformeerde Kerk in Nederland, die Sinode van Emden (1571), bepaal het dat openbare sondes sowel as sondes wat na die onsuksesvolle toepassing van die tug volgens Matteus 18 ' $n$ openbare aard ontwikkel en volhardend die 'algemene welvaart' van die gemeentes skaad of 'de kerken enige merkelijke schade en verderfenis toebrengen mochten ...' deur 'zijn verraderij of verleiding der zielen', deur die 'konsistorie' of kerkraad amptelik of publiek hanteer moet word (Plomp 1971:98; vgl. teks van Emden se kerkorde by Pont 1981:106). Die amptelike kerklike tug moet diegene wat 'tegen de leer van Christus tekeergaan', in toom hou (Plomp 1969:96vv.).

Die Sinodes van Emden (1571) en Den Haag (1586) gee ook nie konkrete maatstawwe oor wanneer 'n sonde 'heimlik' of 'openbaar' is nie. Kruger et al. (1966) vat die saak as volg saam:

Die Kerkorde gee geen aanduiding wanneer ' $\mathrm{n}$ sonde as heimlik en wanneer dit as openbaar beskou moet word nie, want die Kerkorde is geen wetboek wat die strafbare sondes artikelsgewys 
opsom nie ... Met heimlike sondes bedoel die Kerkorde nie die sondes wat ' $n$ oortreder in sy hart koester nie, maar sondes wat al in ' $n$ mate deur woord en daad tot openbaring gekom het: waarvan een of enkele lidmate weet maar die grootste gedeelte van die gemeente nog nie weet nie en wat, as dit wyer bekend sou word, in 'n mindere of meerdere mate oorsaak tot aanstoot en ergernis kan wees. (bl. 434)

Hiermee skets Kruger et al. (1966) die openbare aard van tugwaardige sondes, maar toon terselfdertyd 'n verdere maatstaf vir tugwaardige sondes aan: openbare sondes veroorsaak kerklike 'ergernis' of 'ergenis' in die algemeen. Daarop kom ons terug.

\section{'n Lys van tugwaardige sondes?}

Kruger et al. (1966:434) wys ook op die weiering by gereformeerdes oor baie eeue om sondes vir gebruik te lys en te kategoriseer. Volgens Engelhard en Hofman (2001) het gereformeerdes histories die 'cataloging [of] sins' vermy. Hulle wou ook nie veralgemeende reëls uit hanteerde of vorige sake vir kerkvergaderings in tugsake - die leer van presedente in die publiekreg - formuleer nie (Engelhard \& Hofman 2001:442). So 'n naslaankatalogus of handleiding druis teen die aard en doel van die kerklike tug in: 'n pastorale handeling wat wil trek en in liefde en diskresie dog regverdig met sondaars wil omgaan - 'n pastorale handeling wat elke saak en elke sondaar binne sy konteks op meriete wil hanteer; 'n pastorale handeling wat die eer van God en heil van die kerk wil handhaaf, maar ook die eie plekkie van die sondaar in die kerk wil blootlê en herstel (vgl. Calvyn in Nauta 1971:348; Sadler 1979:9; Sizoo s.a.:260-262; Van Dellen \& Monsma 1967:291).

'n Lys van tugwaardige sondes sonder konteks mis die stelling van Sadler (1979) en ander wat betoog dat die geestelike doel van die kerklike tug die 'grootste speelruimte' in die toepassing daarvan vereis. Hier is nie plek vir mensgemaakte, onbuigbare, vaste voorskrifte nie. Sadler glo dat die toepassing van bybelse beginsels en lewensnorme met liefde en regverdigheid in die omstandighede - met die oog op sigbare, tasbare berou by die sondaar vir sy behoud en vir die herstel van die kerk - die kerklike tug reg stuur. Die kerkorde moenie ' $n$ wet word wat hierdie speelruimte bedreig nie. In die tughandeling moet daar "n hoë mate van soepelheid en aanpasbaarheid wees'. Veral as dit gaan oor die 'tyd en omstandighede' waarin die tug toegepas word. Die gereformeerde vaders was, volgens Sadler (1979:30-34), oortuig dat hulle nie die siel uit die kerklike tug moet verwyder deur 'n 'boekdeel met reglemente' (verpligte detailvoorskrifte) wat aan iets soos die wettiese Roomse Corpus Iuris Canonici kerklike ruimte laat nie.

Visser (1999) wys op 'n 'sondelys' in artikel 80 van die GKSA$\mathrm{KO}$, maar verklaar onmiddellik dat hierdie artikel nie 'n volledige katalogus van sondes wil wees nie. Dit sou 'onmoontlik ... [en] onnodig' wees. Dit gaan oor die vernaamste - aldus Visser - sondes soos simonie, trouelose diensverlating of indringing van ' $\mathrm{n}$ ander se diens, egbreuk en 'gewoontedronkenskap'. ${ }^{6}$ Volgens Visser (1999:284-286) moet 'elke sodanige geval ... volgens eie omstandighede beoordeel en hanteer word'. Die uitkoms van so 'n sonde as tugwaardig sowel as die tugmaatreël moet in die betrokke geval self bepaal word.

Kruger et al. (1966:479) wys daarop dat hierdie sondelysie vanaf die Nederlandse Gereformeerde Sinode van Middelburg in 1581 kom en aan die Geneefse Kerkorde van Calvyn in 1541 ontleen is: die Ordonnances Ecclesiatique artikel 25 en 26 (teks in Pont 1981:26). Soos deur Visser (1999:284286) geoordeel, dui die lys, volgens Kruger et al. ook op die vernaamste openbare, growwe sondes. Die artikel beperk sake egter nie tot hierdie sondes nie en spreek hom ten slotte uit teen alle sondes wat die oortreder in kerk en wêreld eerloos maak. Op sy beurt is die herstel van geskorste of afgesette ampsdraers nie onmoontlik nie. Trouens, die Nasionale Sinode van Emden in 1571 dui 'n pad na herstel aan (Kruger et al. 1966:479).

Op hierdie punt meen die vermaarde kerkregtelike Gysbertus Voetius (1589-1676) (De Jong 1987:266) egter dat herstel in die amp na'n sonde wat die doodstraf kry of sondes soos egbreuk, godslastering, diefstal, hoogverraad en meineed onmoontlik is (Kruger et al. 1966:480). In hierdie opsig ontken hy die diskresie of speelruimte wat, veral later, aan kerkvergaderings gegee word. Die sondes wat hy aandui, impliseer ook dat die assosiasie wat so iets by die kerkvolk wek, onder watter omstandighede ook al, tot permanente ongeskiktheid vir die amp lei. Of daar nou berou, restitusie, herstel en versagtende omstandighede by die dader is of nie, hierdie smet kan in die oë van gemeentes nie weggeneem word nie.

Iets van 'n sondelys of uitsonderlike ergerlike sondes blyk uit NGKO 2017 vir NG-predikante wie se legitimasie as gevolg van hierdie sondes beëindig is. Artikel 66.4 .5 bepaal dat dominees wat as gevolg van 'ergerlike sondes' soos owerspel, onsedelikheid, egskeiding, moord, meineed, diefstal en leerdwaling hulle legitimasie verloor het, anders as in 'ligter' gevalle, slegs by 'hoë uitsondering' weer gelegitimeer kan word. Hierdie stap moet op 'aanbeveling van alle betrokke kerkvergaderings' kom en word alleen deur die Moderamen van die Algemene Sinode 'verleen' (NGKO 2017:20). Hierdie bepaling sonder sommige sondes dus as baie ergerlik uit, maar behou die diskresie van kerkvergaderings vir die herstel van legitimasie onder omstandighede. Wat ook waar is, is dat so 'n sondelys die norm negeer dat alle sondes, afhangende van die tyd, omstandighede en oordeel van kerkvergaderings, ergerlik tot radikaal ergerlik kan wees. Teenstrydig met die diskresie van kerkvergaderings, werk die lys met bepaalde ergerlike sondes onder alle omstandighede in 'n Christelikgereformeerde kerkgemeenskap. Hierdie lys neig om die tydsomstandighede te bowe te gaan.

Die term ergerlike vra om verdere ontleding.

6. Agter hierdie "dopperterm' sit'n etiek wat dui op'n hardnekkigheid of volharding in die oortreding en op 'n onbekeerdheid en geestelike gebondenheid aan die die oortreding en op ' $n$ onbekeerdheid en geestelike gebondenheid aan die
ongehoorsaamheid -' $n$ sondige geneigdheid waarteen die tug juis ingaan (Sadler 1979:57). 


\section{Tugwaardige sondes is ergerlike sondes}

'Ergerlik' dui daarop dat daar ook nie-ergerlike sondes kan wees of sondes waarvoor daar meer kerklike begrip en verdraagsaamheid is. Sadler (1979:62) oordeel dat'n ergerlike sonde daardeur gekenmerk word dat dit dreig om ander tot ongehoorsaamheid aan God te verlei, hulle geestelike welsyn in gevaar stel en veroorsaak dat oortreders slegter word as wat hulle was. Calvyn staan op sondes van verskillende grade van ergerlikheid wat verskillend hanteer moet word. Staan dit vas dat die kerk met 'n openbare, aanstootlike sonde te make het, moet die betrokke vergadering bepaal of dit 'n kleiner of groter afstootlike oortreding is. 'n Hardnekkige volharding met 'n kleiner oortreding kan eventueel tot kerklike afsnyding lei terwyl 'n groter ergerlike sonde dadelik meer drastiese optrede noodsaak (Sizoo III s.a.:259, 261-263).

Die graad van ergerlikheid hang dus af van die effek wat die sonde in die huidige tyd en omstandighede op die kerk en sy wêreld het. Dit is 'n saak waarop daar met kerklike diskresie 'in die lig van die Skrif' besluit moet word. 'In die lig van die Skrif' dui daarop dat dit hier om Skrif en belydenis gaan en dat die saak nie ligtelik deur die kerk hanteer moet word nie. Die oortreding van sekere belydeniswaarhede is die oortreding van kernwaarhede van die geloof wat die ergerlikheid van die handeling verhoog. Ergerlikheid word gestimuleer deur die feit dat die oortreding nie net as verkeerd beoordeel word nie, maar ook as grof, onvanpas en aanstootlik (vgl. GKSA-KO in NGKO 2017:17; Visser 1999:264-265).

Sadler (1979) wys tereg daarop dat daar 'geen objektiewe maatstaf' is om die ergerlikheid van 'n sonde, gemeet aan Skrif en belydenis, te bepaal nie. Of die sonde ergerlik is, of dit deur ander in die gemeente gevolg kan word en smaad oor die Naam van die Here bring, 'is 'n saak wat geheel en al berus in die beoordeling van die kerkvergadering by wie dit aanhangig gemaak is'. Hierdie stelling maak 'n lysie van tugwaardige sondes hoogs onwenslik (Sadler 1979:62).

Ergerlikheid en hardnekkigheid stry of bots met berou. Daarom kan hardnekkigheid die ergerlikheid of aanstootlikheid van 'n oortreding verhoog. Boonop dui hardnekkigheid op 'n gebrek aan berou, inkeer en herstel by die sondaar. 'n Enkele oortreding of 'n volharding in die sonde word ook oorweeg by die tugmaatreël of uitkoms van die tugondersoek. So iets kan die beoordeling van die opregtheid van die berou by die sondaar beïnvloed (Sadler 1979:56-57). Die NGKO (1964:12) het reeds bepaal dat daar onderskeid tussen 'n enkele oortreding en 'n volharding in die sonde getref moet word.

Dat tugwaardige sondes van 'n ergerlike aard is, kom deur die eeue by gereformeerdes voor. Dit gaan hier om 'n aanstootlikheid teen of 'n growwe nalaat van onomstootlike, vaste Skriftuurlike waarhede of beginsels soos deur die kerk verstaan en gepositiveer; nie mensgeoriënteerde bepalings vir kerklike prosedure soos in 'n kerkorde nie. Daarom het NGKO 1998 die bepaling dat sonde teen die Woord en belydenis van die kerk indruis, teruggebring nadat dit in 1978 uitgebrei is met sonde teen die Bybel, die belydenis en die kerkorde (NGKO 1964:12; 1978:15; 1994:13; 1998:21). Die kerkorde lê in hierdie beskouing nie op dieselfde vlak as Skrif en belydenis nie. Die belydenisse word aanvaar 'omdat' (qua) hulle in hulle verwoording van die Christelike geloof met die Bybel ooreenstem (NGK 1998:414-415) en nie tydsgebonde dokumente van kerklike en menslike prosedure is nie. Die kerkorde as 'n maatstaf vir tugwaardige, ergerlike sondes is in 'n tyd aanvaar waarin die Algemene Sinode van die NGK 'n vlaag van reglementeringswoede beleef en 'n nie-gereformeerde tugreglement aanvaar het (Sadler 1979:33-35). Die oortreding van ' $n$ kerkorde moet in beginsel ook ' $n$ doelbewuste oortreding van 'n duidelike bybelse waarheid - soos die oortreding van die vyfde of die gesagsgebod - en van 'n ergerlike aard wees. Boonop is die belydenisskrifte van 'n gereformeerde kerk sy akkoord van kerklike of geloofsgemeenskap - 'n akkoord wat sy geestelike rigting aandui - en nie sy kerkorde nie. Laasgenoemde gaan uit van Skrif en belydeniswaarhede, maar is op die prosedure van kerklike aksies afgestem (Bouwman 1985:556; Strauss 2010:114).

Dieselfde uitgangspunt geld vir die oortreding van die besluite van kerkvergaderings. So 'n saak moet onder die omstandighede as 'n aanstootlike of ergerlike minagting van, byvoorbeeld die vyfde gebod beskou kan word. Daarby moet die effek daarvan op die kerk en sy lidmate in berekening gebring word. Soos 'n burgerlike hof moet kerkvergaderings hulle nie besig hou met beuselagtighede of klein sondetjies nie (Strauss 2010:115). Gereformeerde kerke vra normaalweg van lidmate instemming met hulle belydenisskrifte, maar laat vryheid van gewete - gebonde aan die Skrif - toe om van die besluite van kerkvergaderings en ordes op 'n kerkordelike manier te verskil en dit gewysig te kry. Die legitimasieverklaring van NGK-proponente as voornemende bedienaars van die Woord, bind hulle nie aan die besluite van kerkvergaderings of die bepalings van kerkordes nie, maar aan die Skrif en die belydenis. Verskille met besluite en kerkordes kan openlik verklaar word sonder dat die persoon sy of haar legitimasie in gevaar stel. Hierdie verskille moet egter kerkordelik hanteer, en die sake wat op die rand lê, van beide kante verdra word. Gelegitimeerdes verbind hulle wel daartoe om hulle aan die orde (wyd verstaan) van die NGK te hou (NGKO 2017:53).

\section{Leertug?}

Jansen gebruik 'openbaar' en 'ergerlik' ook as maatstawwe vir 'tuchtwaardige' leersondes (Jansen 1936:83-84).

Hierdie redelik algemeen aanvaarde gereformeerde benadering verskil van die onderskeid van drie of meer dekades gelede in sommige kringe in gereformeerde Nederland tussen judisiële en justisiële tug in leerstellige sake. 
Daarvolgens kan kerkvergaderings wat klagtes rondom die leer van die kerk aanhoor, of volstaan met 'n blote uitspraak, of oordeel in die saak (judisiële tug), of leertug toepas wat tot skorsing en afsetting uit die amp - tradisioneel die dominee kan lei (justisiële tug). Kamphuis (1982) wys daarop dat daar geen bybelse gronde vir hierdie onderskeid bestaan nie, maar vir voorstanders daarvan die 'voordeel' inhou dat verskille oor kernsake ontwyk en 'n kerklike skisma vermy kan word. Boonop skep die betrokke kerke of gemeentes hiermee die beeld dat hulle (darem) die voet dwars sit vir die ontkenning van bybelse waarhede. Die indruk word gelaat dat 'de kerk doen toch wat ...' (Kamphuis 1982:24-25).

Soos by die onderskeid hierbo tussen tugwaardige en ander sondes, tref Jansen (1936:19, 22) 'n onderskeid tussen 'tuchtwaardige' dwaalleer en 'heimlike', 'minder ernstige' of getolereerde dwaalleer.

Ten opsigte van maatstawwe vir minder ernstige dwalings verwys Jansen instemmend na Sinode Den Haag van die Gereformeerde Kerke in Nederland (GKN) in 1914. Behalwe vir die gebruik van die maatstawwe wat gegee word, gaan dit ook om die diskresie van die betrokke kerkvergadering. Die vergadering moet bevind dat die dwaling geen fundamentele afwyking bevat nie, dat die dwaler(s) bereid is om nadere onderrig te ontvang en dat hulle geen propaganda vir hulle afwyking sal maak nie. Sulke gedrag kan verdra en moontlik deur onderrig en oortuiging of oorreding, uitgeskakel word (Jansen 1936:20-22). Vir tugwaardige leersondes gebruik Jansen 'openbaar' en 'ergerlik' as maatstawwe - 'n openbare ergerlikheid wat die gemeente of gemeentes by openbaarmaking die eerste keer tref of volg op 'n vrugtelose, stille vermaning deur die kerkraad (Jansen 1936:23). Vir Jansen is die norme vir leertug ook Skrif en belydenis met 'n tugproses wat die prosedure van die kerkorde volg (Jansen 1936:78).

Hoewel sake van leer en lewe onderskeibaar is, hanteer die drie gereformeerde kerkordes wat hier ondersoek word, tug oor leer en lewe - by implikasie - binne dieselfde prosedure vir die tug. By al drie ontbreek 'n afdeling wat spesiaal aan leertug gewy word. Dit impliseer dat daar, volgens hulle, in die hantering van leersake ook ruimte vir diskresie of 'n speelruimte vir die goeie oordeel van die betrokke kerkvergadering moet wees - 'n speelruimte met die oog op die drieledige doel van tug.

Nie een van die drie kerkordes wy bepalings aan die tug oor dooplidmate of lidmate wat op grond van hulle doop en deel aan die genadeverbond van die Here, lidmate van die kerk is nie. Dooplidmate beskik egter nie oor die lidmaatsvoorregte van belydende lidmate nie: hulle kan nie die sakramente gebruik of tot ' $\mathrm{n}$ amp verkies word nie. ${ }^{7}$ Daarom noem

7.Selfs die NGK wat dooplidmate tot die nagmaal toelaat, vereis dat hulle as gedooptes in Jesus Christus glo, weet wat by die nagmaal gebeur en begeer om aan die nagmaal toegelaat te word (NGK 1998:515). Die toelating geskied onder meer dus op grond van geloof in en belydenis van Jesus Christus. J.A. Heyns beskryf die doop - in ' $n$ persoonlike mededeling - as ' $n$ teken van die inlywing in God se doop - in ' $n$ persoonlike mededeling - as ' $n$ teken van die inlywing in God se
genadeverbond en die nagmaal as ' $n$ teken van die inblywing in dieselfde verbond. genadeverbond en die nagmaal as ' $n$ teken van die inblywing in dies
Daarom moet deelnemers aan die nagmaal hulle geloof kan bely. 'n sinodebesluit van die GKSA in 1961 hulle inkomplete lidmate wat onder inkomplete $t u g^{8}$ staan. In hulle geval word amptelike tugmaatreëls beperk tot vermanings en 'n weerhouding van belydenisaflegging en daardeur die gebruik van die sakramente en die reg om in die amp verkies te word (Den Hartog 1952:16; Visser 1999:262). Die Nederlandse kerkordes van die sestiende eeu met die DKO as die kulminasiepunt (Pont 1981:55-189), wy geen bepalings aan die tug van dooplidmate nie.

Hierdie situasie beteken nie dat die CRC-NA, die NGK en die GKSA nie erns met tugwaardige of openbare ergerlike sondes van dooplidmate maak nie. Inteendeel, hulle bly die 'voorwerp' van kerklike sorg. NGKO 2017 wy artikel 50 uitsluitlik aan 'die jeugbediening' of 'verbondsjeug as 'n geïntegreerde deel van die omvattende gemeentelike bediening' (NGKO 2017:13), terwyl CRC-KO artikel 63 om die versorging van die geloof in Christus Jesus van die jeug in die gemeentes draai (Engelhard \& Hofman 2001:351-355). Gereformeerde kerke soos in die GKSA maak normaalweg erns met kategetiese onderrig (Visser 1999:221). Teen hierdie agtergrond moet die suiwere bediening van die Woord dus tot die kerklike tug lei.

Wat hierdie toedrag van sake wel sê, is dat die dooplidmate van hierdie kerke ook aan die bediening van die kerklike tug met sy uitgangspunte en oogmerke - waar van toepassing blootgestel is.

\section{Slot}

Tugwaardige sondes van kerklidmate strek hulle uit oor die hele leer en lewe - die volle bestaan - van hierdie lidmate. Tug raak die volle bestaan van kerklidmate omdat hulle vanuit die hart voluit wil of moet lewe vir God - die Soli Deo Gloria-beginsel van die sestiende-eeuse Reformasie. Hierdie uitgangspunt bring mee dat alle bedrywighede van die mens sy verhouding met die God van die Bybel kruis of raak en iets van die inhoud daarvan weerspieël. Bedrywighede wat nie noodwendig deel van sy lewe as 'n lidmaat van die georganiseerde kerk is nie, maar tog die klop en rigting van sy geestelike hart verraai. Die bediening van die tug is 'n bediening van die omgeeliefde van die Here van die kerk vir sy kinders. Liefde wat diegene trek wat 'tegen de leer van Christus tekeergaan' (Plomp 1969:96vv.). Die kerklike tug is geestelik van aard en op die geestelike of geloofskante van die menslike bestaan gerig. Die doel van die kerklike tug by gereformeerdes, naamlik die eer van God, die heil van die gemeente en die behoud van die sondaar, onderstreep hierdie geestelike karakter (NGKO 2017:17).

God se heiliging van gelowiges wat dit nie verdien nie, is die gevolg van sy verlossende, toegekende geregtigheid of 'compassionate justice'. Om as gevolg hiervan geregverdig te lewe is genade, maar ook 'n teken van die deurwerking van sy geregtigheid. Daarom is kerklike tug deel van sy 8.Die terme compleet en incompleet word vroeër ook deur "den groten canonicus Gijsbertus Voetius' gebruik (Den Hartog 1952:13-17). 
toegekende, geskenkte geregtigheid - 'n teken van sy verbondstrou (Smit 2009:377).

Tugwaardige sondes is ' $n$ naam vir daardie sondes wat onder die aandag van sekere kerkvergaderings van die CRC-NA, die NGK en die GKSA kom - 'n hantering wat via hulle kerkordes aan hierdie vergaderings toegewys word.

In hulle hantering van die kerklike tug moet kerkvergaderings die draers wees van God se omgeeliefde en geskenkte geregtigheid. Dit beteken dat die Skrif en die kerklike belydenis hulle maatstaf vir dit wat reg en goed is, moet wees. In hulle gebruik hiervan in bevindings, moet hulle ter wille van die geestelike sekerheid en die welsyn van lidmate konsekwent wees en wat hulle algemene rigting betref, voorspelbaar. Daarby moet hulle uit Christelike liefde medemenslik en regverdig wees.

Die maatstawwe vir tugwaardige sondes onder gereformeerdes, naamlik openbare ergerlike sondes in die lig van Woord en belydenis, leen hulle nie tot 'n wettiese benadering of 'n vooraf vasgestelde en kontekslose sondelysie en tugprosedures nie. Dit vra eerder vir insig en diskresie vir die beoordeling van die saak in die tyd en omstandighede. Dit vra ook vir 'n speelruimte waarin diskresie met 'n aanvoeling vir die situasie en Woord en belydenis aangewend word.

Die bevindings van kerklike tugvergaderings moet trek en oortuig.

\section{Erkenning \\ Mededingende belange}

Die outeur verklaar dat hy geen finansiële of persoonlike verbintenis het met enige party wat hom nadelig of voordelig kon beïnvloed het in die skryf van hierdie artikel nie.

\section{Literatuurverwysings}

Bouwman, H., 1985, Gereformeerd Kerkrecht II, 3e druk, De Goot Goudriaan, Kampen.
Coertzen, P., 2003, 'Regsbeskerming in die kerk', in R. Torfs, K. Martens \& L.J. Koffeman (eds.), Recht op recht in de kerk, pp. 199-258, Peeters, Leuven.

De Jong, O.J., 1987, Geschiedenis der kerk, Callenbach, Nijkerk.

Den Hartog, G.M., 1952, De tucht over doopleden, Van den Brink, Zutphen.

Donner, J.H. \& Van den Hoorn, S.A., s.a., Acta Nationale Synode te Dordrecht, Donner, Leiden.

Du Plooy, A. le R., 2007, 'Beginsels vir regspraak in die kerk', Die Kerkblad, April, 18-20.

Engelhard, D.H. \& Hofman, L.J., 2001, Manual of Christian Reformed Church Government, CRC Publications, Grand Rapids, MI.

Jansen, J., 1936, De leertucht, Kok, Kampen.

Jansen, J., 1952, Kerkorde der Gereformeerde Kerken, Kok, Kampen.

Jonker, W.D., 1994, Bevrydende waarheid: Die karakter van die gereformeerde belydenis, Hugenote-Uitgewers, Wellington.

Kamphuis, J., 1982, Om de heiligheid van de gemeente, Van den Berg, Kampen.

Keet, B.B., 1963, Orde in die kerk, NG Kerk-Uitgewers, Kaapstad.

Koffeman, L.J., 2009, Het goed recht van de kerk, Kok, Kampen.

Kruger, L.S., Du Plessis, H.L.M., Spoelstra, B. \& Spoelstra, T.T., 1966, Handleiding by die kerkorde, Pro Rege, Potchefstroom.

Nauta, D., 1971, Verklaring van de kerkorde van de Gereformeerde Kerken in Nederland, Kok, Kampen.

Nederduitse Gereformeerde Kerk, 1998, Handelinge van die Algemene Sinode, s.n., s.I. Nederduitse Gereformeerde Kerkorde, 1964, Kerkorde, NG Kerk-Uitgewers, Pretoria. Nederduitse Gereformeerde Kerkorde, 1978, Die Kerkorde, NG Kerkboekhandel Transvaal, Pretoria.

Nederduitse Gereformeerde Kerkorde, 1994, Die Kerkorde, Hugenote-Uitgewers, Wellington.

Nederduitse Gereformeerde Kerkorde, 1998, Die Kerkorde, Hugenote-Uitgewers, Wellington.

Nederduitse Gereformeerde Kerkorde, 2017, Die Kerkorde, sn, sl.

NGK sien Nederduitse Gereformeerde Kerk, 1998.

NGKO, sien Nederduitse Gereformeerde Kerkorde.

NG Kerk-Uitgewers, 1982, Ons glo ... Die Drie Formuliere van Eenheid en ekumeniese belydenisse, NG Kerk-Uitgewers, Wellington.

Plomp, J., 1969, De kerkelijke tucht bij Calvijn, Kok, Kampen.

Plomp, J., 1971, 'De Kerkorde van Emden', in D. Nauta, J.P. van Dooren \& O. de Jong (eds.), De Synode van Emden Oktober 1571, pp. 88-121, Kok, Kampen.

Polman III, A.D.R., s.a., Onze Nederlandsche Geloofsbelijdenis III, Wever, Franeker. Pont, A.D., 1981, Die historiese agtergronde van ons kerklike reg I, HAUM, Pretoria. Sadler, T.H.N., 1979, Die kerklike tughandeling, NG Kerkboekhandel, Pretoria.

Sizoo, A., s.a., Johannes Calvijn Institutie III, Meinema, Delft.

Smit, D.J., 2009, Essays on being reformed, Sun Media, Stellenbosch.

Strauss, P.J., 2010, Kerk en orde vandag, Sun Media, Bloemfontein.

Strauss, P.J., 2017, 'Die geestelike aard van die kerklike tug', Stellenbosch Theological Journal 3(1), 375-389. http://dx.doi.org/10.17570/stj.2017.v3n1.a17

Spoelstra, B., 1989, Gereformeerde kerkreg en kerkregering, Teologiese Skool Gereformeerde Kerke in Suid-Afrika, Hammanskraal.

Van Dellen, I. \& Monsma, M., 1967, The revised church order commentary, Zondervan, Grand Rapids, MI.

Van der Vyver, J.D., 1972, Die juridiese funksie van staat en kerk, Butterworths, Durban. Visser, J., 1999, Die Kerkorde in praktyk, EFJS, Orkney. 